\title{
A study on Pro-environmental attitudes and product attributes of the consumer's and their impact on purchase behavior of environmentally safe fashion product
}

\author{
Avinash ReddyNandikonda ${ }^{1}$, Praveen Kumar Munari ${ }^{2}$ \\ ${ }^{1}$ Post graduation scholar, School of business, Woxsen University, Telangana, \\ India \\ ${ }^{2}$ Post graduation scholar, School of business, Woxsen University, Telangana, \\ India \\ Iavinashreddy.nandikonda_2022@woxsen.edu.in, \\ ${ }^{2}$ praveenkumar.munari_2022@woxsen.edu.in
}

\begin{abstract}
:
This study is done to investigate whether the environmental attitudes and product attributes of eco-friendly products, perceived importance of a company's environmental activities influence the consumer buying behavior of environmentally friendly fashion goods, which also includes the satisfaction of the consumers towards the eco-friendly fashion products. To conduct the study, the authors have prepared a questionnaire suitable for the study which was responded to by 400 people. In our study, the authors obtained the results that consumer's environmental concern and their purchases of environmentally safe household items have a positive influence on the purchasing of environmentally safe fashion products by consumers. Second, the authors found that the importance of the buyer to the products eco-friendly attributes has a (+ve) influence on the buying behavior of environmentally safe fashion products. Third, the authors found that the corporate environmental activities value is not having a significant effect on the consumer's purchase habits of environmentally safe fashion items. Finally, the authors found that consumers' purchase behavior of environmentally safe fashion products has a huge positive influence on the satisfaction, trust of the consumers, and repurchase intention of the consumers. Where the authors have found that the trust and satisfaction of customers lead to the intention to repurchase environmentally safe fashion goods. Here the research implication was discussed.
\end{abstract}


Keywords: Eco-friendly fashion products, consumer's attitude towards the environment, consumers importance to the eco-friendly product attributes, purchase behaviour eco-friendly fashion products, perceived corporate value.

\section{Introduction}

Consumers' perception of the environment is changing day by day. Awareness about the protection of the environment increasing consumers having more tendency to buy ecofriendly products. Most fashion companies trying to develop green marketing strategies. To save the environment most governments are developing eco-friendly products. As fashion companies are the most pollution-creating industries. They need to decrease pollution to develop trust among the consumers. Consumers are having more tendency to buy fashion products due to their concern for the environment (Cheah, Phau, \& Planning, 2011). As the fashion industry is the one which produces $20 \%$ of water pollution, $10 \%$ of carbon emissions the corporates need to develop sustainable fashion growth, if this pollution goes on the increase by 2050 fashion industry may create $26 \%$ of carbon footprints these factors leading fashion industries to develop eco-friendly products (Morgan, 2021).

When consumers are targeted towards the purchasing of eco-friendly fashion products, they are considering different attributes of the product like the label, ecofriendly mark, and quality of the product. fashion industries are trying to develop their products by considering these factors to increase their sales (Blasi, 2019)

Satisfaction plays a major role in the repurchase of the product, satisfaction depends upon the product performance and awareness of the product to the customers (priyanandhini. $\mathrm{n}, 2018$ ).

\section{Literature Review}

\subsection{Bio spheric values related to Pro-environmental purchase}

\section{behaviour}

The attitudes of consumers influence positively depending upon the consumer biospheric values in the direction of environmental conservation, which in turn persuade consumers to buy environmentally friendly or energy-efficient products. Which helps in targeting the customers who have strong bio spheric values. Many environmental policies are implemented to reduce the dangerous impact of the environment due to plastic pollution and less bio spheric values among the population and more usage of non-eco-friendly products. It is critical to raise consciousness among the individuals to benefit the environment and community.

Bio spheric values influence the consumer's subjective norms, and it does not support the purchase behaviour of environmentally safe products. This is due to no awareness among the policies, policymakers should run campaigns to communicate with people to raise 
awareness among the people about benefits obtained by pro-environmental purchase behaviour.

Consumers perceived discomfort because they purchased eco-friendly items. depends upon the bio spheric values of the consumers. Consumers essentially with strong bio spheric values are okay with the presumed annoyance caused by material non-availability, higher prices, to reduce consumers inconvenience marketers should provide attractive signage in purchasing the products and they should provide more accessibility of the environmentally safe items (De Groot \& Steg, 2009).

To purchase environmentally sustainable goods consumers should have strong bio spheric values those should be influenced by marketers, they should be given awareness among the eco-friendly products and how they are impacting the environment in which these type campaigns influence to rise in bio spheric values in which this also positively impact purchase behaviour of the eco-friendly products (Nguyen, Lobo, Greenland, \& Services, 2016).

\section{Purchase Situation}

The purchase situation moderates the purchase intention and behaviour towards the products in which changes pro-environmental consumer behaviour. One of the factors that affect purchasing intention is time constraints. The importance of price influences the intention to buy eco-friendly goods. Situational influences are the temporary factors that change the buyer's behaviour. They are like physical factors, time factors, buyer's mood at that time, social factors, and the reasons for the purchase. Individual factors are caused due to life experiences like values, attitudes, and personality of the consumer which also affect the decision-making process of the consumer. The variables of individual emotions, attitudes, perceived market efficacy, perceived behavioural regulation, beliefs, and personal norms, confidence, and awareness are all factors that influence consumer behaviour. Situational factors are the forces that are caused during the purchasing of environmentally safe products: price, the product's availability, subjective or social standards, product consistency and characteristics, store-related attributes, brand value, eco-labelling, and certifications are all factors to consider(Joshi \& Rahman, 2015). Various studies proved that lack of trust among the consumers in the ethical claims and characteristics of Consumer attitudes against eco-friendly goods is often influenced by eco-friendly products. Inconsistency in attitude-behaviour is caused by the consumer's loss of confidence. towards the product which makes barriers to purchase eco-friendly products. Most studies reported that consumers' concern on the issues related to environmental and social issues and green attributes and functions are the major motives that drive the intention of consumers to purchase eco-friendly products(2012books.lardbucket.org, 2021).

\section{Eco-friendly product attributes}

The important product attribute is pricing most consumers like to prefer price when buying an eco-friendly product. Eco-friendly products having high costs impact negatively buy these products, experts say that products price should be reduced such that which makes consumers buy more eco-friendly products which contribute to a decrease in non-eco-friendly product consumption and an increase in eco-markets(Majláth, 2009). 
Sometimes the cost makes it difficult for the consumers to buy eco-friendly products but these products last longer and have more benefits than non-eco-friendly products. Some of the benefits are healthier living, better quality, lower maintenance, energy savings, and they are reusable and recycled after use(thechicagogreenbox.com, 2020).

\section{Corporate social responsibility}

Perceived environmental responsibility has a greater influence than perceived social responsibility. CSR actions help to generate value for the consumers that means consumers verify the positive actions taken by the company on the environment which results in changes in the purchase behaviour for the brands who take CSR measures than those who do not. Higher satisfaction and loyalty increase the profits of the company. As the perceived value of the consumers is described as a trade-off between the sacrifices of the consumers and benefits of the consumers, CSR actions directly impact the stakeholders and therefore it creates increased benefits(Lyon, Maxwell, \& policy, 2008).

\section{Relational variables and perceived value}

In variables like perceived value, commitment to the brand and trust depends upon the CSR which influences these variables, which results in an increase in loyalty and satisfaction towards the brand. The organizations should maintain the consumer needs and understand their needs to adapt consumers towards their brand. The relational marketing technique is one of the techniques which helps in maintaining the relationships between the consumer and the brand where organizations adapt towards relationships between consumers and their environments. The relational approach increases interchanges in the organizations which allows higher benefits and increased profits in the organization and improved service.

Trust is the most significant aspect that drives customer behaviour, and is dependent on the consumer's values, emotions, and desires about the brand, by placing a premium on the company's credibility, which places a premium on CSR. Commitment comes out from the wishes of the consumer and their relationship with the organization, three elements like commitment should be long term the parties must maintain relationship behind the transaction and second commitment reflects upon the personal predisposition to continue relationship behind the obligations that occurred legally and third commitment is that consumers maintain the relationship if they obtain long term benefits from the organization has direct and positive influence upon the relationship between consumers and organizations(Loureiro, Sardinha, \& Reijnders, 2012).

\section{Demographic characteristics affecting purchase behaviour of eco-friendly products}

Environmentally friendly product consumption depends upon the demographic variables with the choices and their tastes. Age, ethnicity, education level, marital status, and income level are all demographic characteristics. Gender has a crucial role in 
environmental consumption. As different age groups have different needs age is a strong determinant in purchase behaviour. Young people are more willing to talk about environmental issues. More women than men purchase environmentally safe products. Gender affects the purchase behaviour of environmentally safe products. As the buyer age demographic grows, so will the buying of environmentally friendly goods., which means purchase behaviour of the environmentally safe products increases while the age increases, elder consumers are the most interested people in buying eco-friendly products. Marital status also exhibits the difference between the consumer behaviour, people who are married and had more children purchase eco-friendly products than anyone. The quality of education has a major influence on product purchasing decisions, people who are well-educated show importance to the eco-friendly products, due to the awareness ty have on the products, while people with a low level of education exhibit a low level of purchase of eco-friendly products. People with low-income levels may not be able to afford eco-friendly goods, but as income levels grow, the consumption of environmentally safe products may rise as well. As a result, population characteristics play an important part in the purchase of environmentally friendly goods (Ekinci, 2014).

\section{Evolution of Green marketing}

A seminar on ecological marketing organized by AMA (American marketing association) where the term green marketing emerged in the discussion and placed in the literature in 1975. The word "green marketing" became popular in the late 1980s(Tiwari, Tripathi, Srivastava, \& Yadav, 2011).

The history of green marketing can be divided into three stages:

The first phase of green marketing was ecological green marketing, where marketing activities to help environmental problems and concerns towards the environmental problems and remedies towards these problems emerged.

Environmental green marketing is the second phase where the focus is mainly on clean technology, which helps in taking care of pollution and the waste issues caused by innovation in the designs of new products.

Sustainable green marketing is the third phase that helped in developing good quality products, which mainly focused on the quality, convenience, pricing, and performance of the product in an environmentally friendly way.

\section{Why are firms using green marketing?}

\subsection{Opportunity}

In India, $28 \%$ may be conscious about their health and $25 \%$ of the consumers prefer environmentally friendly products. 


\subsection{Social responsibility}

As the companies realized that social responsibility makes more profits in the organizations. So, achieving these responsibilities may rise in brand image these scenarios made companies behave towards environmentally friendly.

\subsection{Governmental pressure}

As the regulations came into existence to protect consumers and society, many companies started showing responsibility towards the environment which also reduced the production of harmful goods. For example, banning plastic bags to protect the environment.

\subsection{Competitive pressure}

Most of the firm's competitive in positioning their business in the top-level among other firms as one firm exhibits behaviour towards the environment other firms also emulate their behaviour due to competitive pressure.

\subsection{Cost reduction}

The harmful waste reduction may lead to substantial cost savings. Sometimes other companies use the waste generated by one company as cost-effective material to reduce the costs (Bahadur, 2019).

\section{Green purchase behavior}

Purchasing environmentally friendly products and like recycled products or products which give benefits to the environment is called green purchasing behavior. Consumer behavior is influenced not only by mood but also by cognitive influences like concern towards the environment, knowledge of the environment. In which these factors additionally reflect on the behavior of the person towards social responsibility to save the environment and which rises his intentions to protect the environment. So that environmental concerns impact the purchase intention of the green products these factors depend upon the awareness among the individuals(Chan \& marketing, 2001).

\section{Customer environmental concern's psychological determinant}

Customer commitment towards the environment changes the purchase behaviour of the products like the value of customer awareness and attitudes toward the 
environment changes the purchase behaviour. The most important components of purchase behaviour towards the individual are cognition, conation, and affection. A relation between green purchase and ecological knowledge(Beckmann, 1993). More knowledge of the environment gives rise to more attitudes towards ecological products(Marvi, Minbashrazgah, Zarei, \& Baghini, 2020).

The relationship between green perceived worth, green confidence, happiness, and desire to repurchase

The components that drive green purchase intentions are trust, satisfaction, and perceived value, Companies should boost these factors to improve purchase behavior. Consumer perceived value depends upon the factors of what is received and the factors of what is given in which these two factors relate to the overall consumer evaluation. Perceived importance is essential in buying decisions because it affects and drives the customer's trust and repurchase intentions. If the service or the product meets the consumer's expectations the consumers will be satisfied which influences the repurchase intention of the consumer. Trust depends upon the expectations of the customers from the product or service, it also depends on the party's strength, dependability, and goodwill. The belief of the consumers also plays a major role in repurchase intentions like environmental credibility. To improve the relationship between the green consumer's organizations, companies must increase green confidence among customers and build the green value of the product or service.

Marketing giants like Coca-Cola have been working on water scarcity; they tend to reduce the usage of more water by improving products like powdered drinks. Facebook is also working to reduce carbon footprints by using $25 \%$ clean energy. So that every organization should promote green value which helps to rise in consumer repurchase intention. More communication strategies using advertising also help to promote the green perception towards the company which rises purchase intention among the consumers. Since green technologies are still in the early stages of growth, customers use a variety of green products or services, and their green value is viewed differently by different people(Lam, Lau, \& Cheung, 2016).

\section{Attitudes towards environmentally friendly products}

Attitudes of the consumer depend upon the knowledge that consumer has on environmental and pollution, the causes that impact the environment which increases their awareness towards the eco-friendly products which in results helps the consumers to develop favourable attitudes towards the purchase of the ecofriendly product. The policymakers and organizations need to run campaigns and advertisements to spread awareness among the customers which rise towards the 
increase in purchase behaviour of environmentally friendly products. Consumers who are optimistic about the future are more likely to purchase environmentally safe products. In which this case rises to more adoption and enhancement of ecofriendly products by improving technologies and developing innovative products. In which these factors improve the brand position than the competitive brands. As a result, brand organizations will demonstrate to customers that eco-friendly brands are priced higher. The adoption of eco-friendly products and enhancement of the various product strategies for economic products and Implementing ecodesign principles such as food packaging, safety, and design, as well as product labelling and placement, allows buyers to buy environmentally friendly goods. (Cheah et al., 2011).

\section{The environmental consciousness of consumers}

The tendency of how mentally an individual reflects on the environment and in which his behavioural and psychological states reflect the commitment towards the environment refers to environmental consciousness. Attitudes play a critical role in determining an individual's or a consumer's environmental consciousness. The values and beliefs of the consumer influence the product attributes their perception towards the product will be different in which this impacts their attitude towards the product. In recent years, the damage caused to the environment impacted more consumers which developed environmental consciousness. In them, this factor changed a few individuals' attitudes towards the environment. In which some studies proved that attitudes of the consumer towards the environment strongly influence the purchase intention or consumption of eco-friendly products(Huang, Lin, Lai, \& Lin, 2014).

\section{Ethical principles for eco-friendly management (corporate responsibility)}

Ethical management is not only for good business management but also for environmental values. Businesses should develop and monitor and as well as implement environmental policies along with environmental strategies and programs. Organizations should do certain tasks for eco-friendly development(Cirstea, 2013).

They should develop and implement the environmental policies and strategies for sustainable development in the corporate world.

All goods and services procurement should be done sustainably.

Implementation of the environmental policies and leading them 
Ensuring commands from environmental legislations

Environmental performance auditing and reporting to internal and external clients regarding the performance and analyzing the situation with the help of regulatory bodies.

Carrying our certain assessments to reduce organization environmental risks and financial costs.

Raising awareness among all individuals and all levels of the organization about the emerging environmental issues and helping them to understand the social responsibility towards the environment.

Environmental issues and responsibilities should be known to all levels of the staff by training them(Karataş, 2015).

As humans are only capable of shaping their nature, organizations need to raise awareness among all the issues and internal factors causing environmental issues and allow them to use environmentally safe products. Corporates have a minimum commitment to educate employees and increase consciousness among employees so that their views toward purchasing environmentally sustainable goods improve.

\section{Consumer decision making in purchasing eco-friendly products}

Consumer decision-making depends upon the factors affecting transitions of ecofriendly products decision-making stages. The stages are thinking(cognitive) consists of knowledge and awareness of the consumer, affective(feeling) consists of preference and interest of the individual, and then attitude-behaviour consists of intention to purchase the product and intention to use the product also called as conative (doing)(Shim, Shin, \& Kwak, 2018).

With the relative benefit, there would be little effect on customer decision-making. Compatibility affects the relative affective and cognitive stages of consumers' decision-making processes. Observability also shows the positive impact on the stages of cognitive and effectiveness, whereas it does not show any impact on the cognitive stage. Complexity has no impact at any stage of the decision-making process. According to Rogers having greater variability increase in innovations and adapting to the innovations. In the consumer decision-making process, a review of the consumers is important. All product buying behaviour follows the same decision-making phases, but the factors that influence it differ from product to product (Rogers, 2010). 


\section{Research methods}

\section{Research questions}

1) Does the corporate environmental activity's perceived importance make an impact on the Purchases of environmentally conscious apparel goods

2) Does Purchasing habits of environmentally safe fashion products impact trust, repurchase intentions, and satisfaction.

3) Do the eco-friendly attitudes of the customers and their importance to ecofriendly product attributes impact the purchase behavior of environmentally safe fashion products.

\section{Data collection and analysis}

This study on eco-friendly fashion products is done by collecting 350 responses mostly from young people where their purchasing experience and their attitudes are selected as the subject for our paper. As most of the young generation are frequent buyers of their household items and travel the most and have educated most this made me make a questionnaire suitable for them. As their interest in the environment and their practices towards protecting the environment, their corporate environmental activities are implemented in the questionnaire. Where step by step questions are included such that the questionnaire is collected and supplemented among the people. Where the description is stated as eco-friendly fashion product purchasing behaviour and concerns around eco-friendly fashion product purchase stated like what type of natural products you use and asked whether they use recycled products and questions related to the price factor. A survey is conducted from Dec 2020 to Feb 2021 and distributed digitally and shared with everyone the authors got 400 responses and these responses are taken for final analysis.

Where all these data are analysed using SPSS software, where statistical analysis is done, EFA (exploratory factor analysis) like correlation analysis and factor analysis were conducted on our data. Validity and reliability tests are done. Cronbach's alpha is used to test the precision sphere's reliability. Next, the authors have checked the relationship between each and concept using structural equation model analysis (SEM) by verifying and identifying the model which will fit. 


\section{Results and discussion}

\section{Validity and reliability}

In our study, the authors used reliability and validity metrics to verify the tests the authors first examined all the concepts where the authors have done EFA(exploratory factor analysis) the authors obtained results for 3 and 2 questions regarding the importance of the eco-friendly attributes of the fashion products which consists of the purchase of fashion product and how satisfied the consumers are weakening the credibility analysis of the concept so these items are excluded and reanalysing of the items is done which gave the result as shown in the table: 1 which shows eigenvalue is 1.0 for most of the factors where the variance was $78.96 \%$ as each constructs Cronbach's value must be at least 0.72 so the consistency of the internal construct will fit. Here the label or factor 1 is that when purchasing eco-friendly products, the attributes are considered generally they are color, design, price, and what brand does the product is. Factor 2 is that fashion products are related to the consumer use of eco-friendly like organic and natural materials containing products, it also consists of information about the purchasing behaviour of the environmentally safe fashion products so that it is called ecofriendly purchase behaviour. Factor 3 is about the companies which produce ecofriendly products such that it contains information about these factories whether they are responsible and carry out any environmental activities. It asks about the opinion of eco-friendly activities from these companies, and it is named as perceived value. Factor 4 consists of interests and beliefs about environmental activities, it has information about what are the consumer beliefs towards the protection of the environment. factor 5 is about trust in eco-friendly products, it has information about consumer's trust in the products they purchase, like whether the products are reliable, sincere, and honest. Factor 6 is about the purchase of eco-friendly household items it contains information about whether the consumers prefer biodegradable products, products from environmentally responsible companies, price of the product. Factor 7 discusses the repurchase intention of the customers whether the customer repurchases if the price increases, a little drop in the quality. Factor 8 has information about attributes of whether the eco-friendly product's price, color, style, and brand are preferred by customers. Factor 9 has information about how happy customers are with the content, style, and price of environmentally friendly goods. Factor 10 is having information about the environmental concern behaviour whether the consumers have a concern regarding the environment and use eco-friendly products. 
Table: 1 - factorial analysis in SPSS

\begin{tabular}{|l|l|l|l|}
\hline Construct & $\begin{array}{c}\text { No. } \\
\text { of } \\
\text { items }\end{array}$ & $\begin{array}{l}\text { Eigenvalues } \\
\text { (\% of } \\
\text { variance })\end{array}$ & $\begin{array}{l}\text { Cronbach's } \\
\text { alpha }\end{array}$ \\
\hline Importance_of_eco-friendly_attributes & 3 & $\begin{array}{l}9.67 \\
(29.29)\end{array}$ & 0.88 \\
\hline $\begin{array}{l}\text { The_purchasing_behavior_of_eco- } \\
\text { friendly_fashion_products }\end{array}$ & 4 & $\begin{array}{l}3.12 \\
(9.34)\end{array}$ & 0.86 \\
\hline Environmental_belief & 3 & $\begin{array}{l}2.25 \\
(6.81)\end{array}$ & 0.92 \\
\hline Perceived_value_of & 3 & $\begin{array}{l}2.45 \\
(7.34)\end{array}$ & 0.93 \\
\hline the_corporate_environmental_activity & 3 & $\begin{array}{l}2.12 \\
(6.45)\end{array}$ & 0.95 \\
\hline Trust & 3 & $\begin{array}{l}1.14 \\
(3.45)\end{array}$ & 0.76 \\
\hline Purchasing_of_eco-friendly_household & 3 & $\begin{array}{l}4.64 \\
(5.12)\end{array}$ & 0.96 \\
\hline items & 3 & $\begin{array}{l}1.36 \\
(4.54)\end{array}$ & 0.74 \\
\hline Repurchase_intention & 3 & 1.26 & $(3.82)$ \\
\hline Importance_of_general_attributes & $3.24)$ & 0.96 \\
\hline Environmental_concern_behaviour & 3 & \\
\hline
\end{tabular}

\section{Model analysis results}

Next, I have checked whether the model is fit or not using the measurement model 
Table:2 - Goodness fit test for structural equation modeling (SEM)

\begin{tabular}{|l|l|l|l|l|l|l|l|l|}
\hline Model & $\mathbf{x}^{\mathbf{2}}$ & df & $\begin{array}{l}\text { Normed } \\
\text { chi- } \\
\text { square }\end{array}$ & $\begin{array}{l}\text { p- } \\
\text { value }\end{array}$ & GFI & AGFI & CFI & RMSEA \\
\hline $\begin{array}{l}\text { Study } \\
\text { model }\end{array}$ & 644.02 & 446 & 1.44 & 0.00 & 0.91 & 0.90 & 0.92 & 0.05 \\
\hline
\end{tabular}

In our study, the authors have done a structural equation model and the model has obtained a good fit. The authors will see how well the model fits when looking at the table: 2 model's index $\mathrm{x}^{2}=644.02, \mathrm{df}=441(\mathrm{P}=.00)$, coming to $\mathrm{NC}=2.18$ which should be less than $3, \mathrm{GFI}=0.91$ which should be greater than $3, \mathrm{AGFI}=$ 0.90 which should be greater than $0.9, \mathrm{CFI}=0.92$ which should be greater than 0.90 , RMSEA $=0.05$ which should be less than 0.08 by looking to this study model and recommended model the authors can say that the model is a good fit. by looking at the $\mathrm{x} 2$ the $\mathrm{p}$-value does not meet the required criteria, but the authors can observe that GFI value, RMSR, RMSEA, AGFI, NFI, CFI is good by comparing them with the recommended acceptable values. So that the authors can say that the model is fit, and this model is useful to explain the relationship between the required concepts and their influence.

Table:3 - Significant constructs of our model

\begin{tabular}{|l|l|l|l|l|}
\hline Path & Beta & $\begin{array}{l}\text { t- } \\
\text { value }\end{array}$ & $\begin{array}{l}\text { p- } \\
\text { value }\end{array}$ & significant \\
\hline $\begin{array}{l}\text { Environmental_concern_behaviour } \rightarrow \\
\text { Purchase_Behaviour_of_eco_friendly_fashion_products }\end{array}$ & 0.20 & 2.54 & $<0.05$ & yes \\
\hline $\begin{array}{l}\text { Purchasing_of_eco_friendly_household_items } \rightarrow \\
\text { Purchase_Behaviour_of_eco_friendly_fashion_products }\end{array}$ & 0.32 & 4.08 & $<0.01$ & yes \\
\hline $\begin{array}{l}\text { Eco_friendly_attributes } \rightarrow \\
\text { Purchase_Behaviour_of_eco_friendly_fashion_products }\end{array}$ & 0.22 & 2.98 & $<0.01$ & yes \\
\hline $\begin{array}{l}\text { Purchase_Behaviour_of_eco_friendly_fashion_products } \\
\rightarrow \text { satisfaction }\end{array}$ & 0.56 & 7.11 & $<0.01$ & yes \\
\hline $\begin{array}{l}\text { Purchase_Behaviour_of_eco_friendly_fashion_products } \\
\rightarrow \text { trust }\end{array}$ & 0.26 & 4.54 & $<0.01$ & yes \\
\hline $\begin{array}{l}\text { Purchase_Behaviour_of_eco_friendly_fashion_products } \\
\rightarrow \text { repurchase_intention }\end{array}$ & .043 & 6.11 & $<0.01$ & yes \\
\hline \begin{tabular}{l} 
Satisfaction $\rightarrow$ trust \\
\hline Satisfaction $\rightarrow$ repurchase_intention
\end{tabular} & 0.34 & 4.98 & $<0.01$ & yes \\
\hline \begin{tabular}{l} 
Trust $\rightarrow$ repurchase_intention \\
\hline
\end{tabular} & 0.18 & 2.54 & $<0.01$ & yes \\
\hline
\end{tabular}


Figure:1 - SEM model

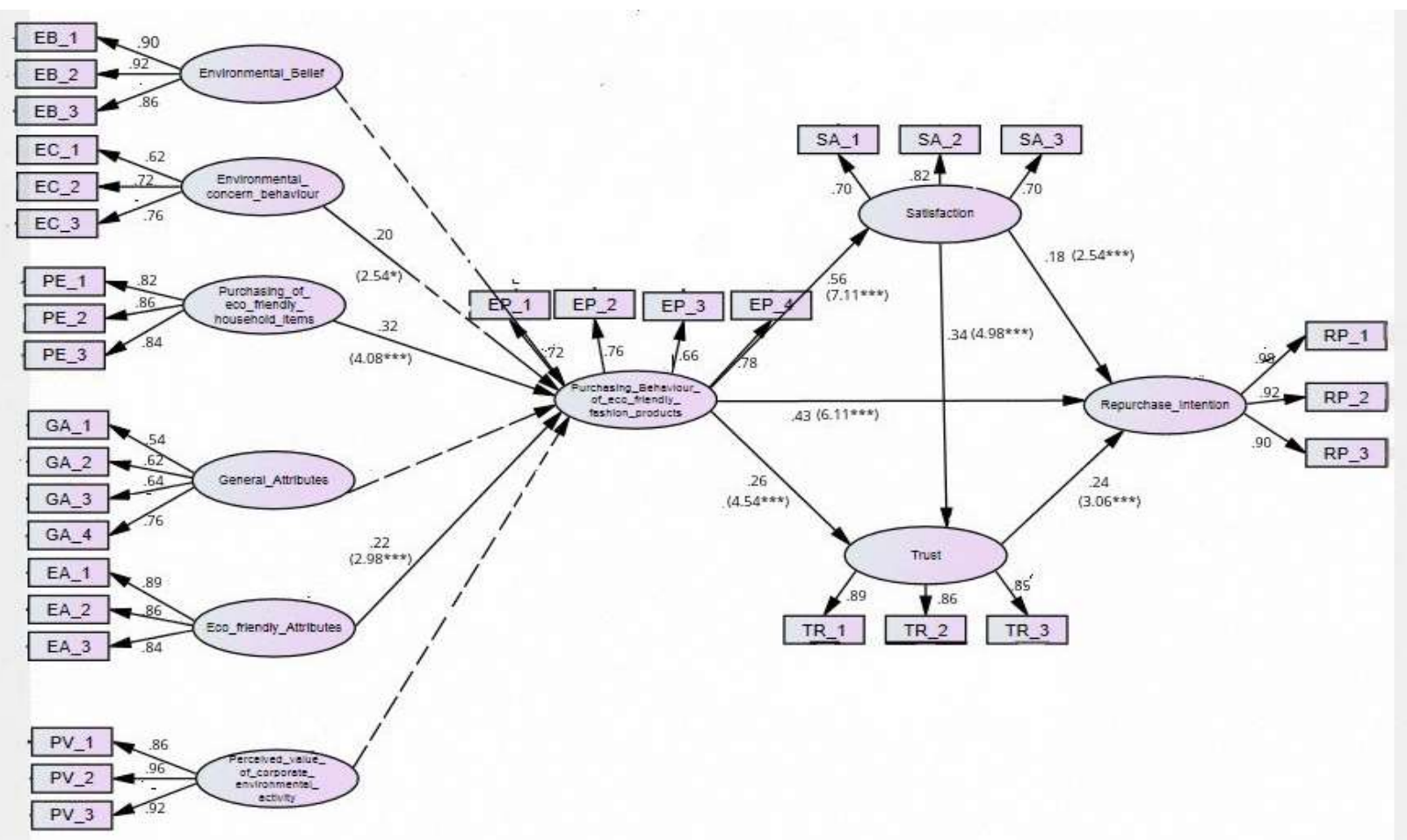

Here $* * * p<.001, * \mathrm{p}<0.05$

Hereby examining constituent concepts and their relationships, from the figure: 1 the authors can observe that the respondent's behaviour concern towards the environmental protection their attitude towards the environment $(\mathrm{t}=0.20, \mathrm{p}<$ $0.05)$, and purchase behaviour of eco-friendly household items $(t=4.08, p<0.001)$ towards The buying of eco-friendly fashion goods is significantly beneficial, and it has been discovered that buying eco-friendly household objects and demonstrating environmental concern and conservation are linked and has a significant effect on the purchase behavior.it means if there is more concern towards the environment then consumers more tend to select eco-friendly fashion products and tend to purchase them. So that the people need to show concern towards the environment, and it should be important for the people to get awareness on protection of the environment. People who give more importance to the climate are more likely to buy environmentally safe fashion goods. and tend to buy more environmentally safe fashion products. By this study, the authors can say that the pro-environment attitudes of the consumers lead to a rise in purchase behaviour of environmentally safe fashion products.

By analysing the impact of environmentally safe product characteristics on the purchasing behaviour of environmentally safe fashion products, the authors can conclude that the properties of eco-friendly products such as product packaging, scale, and versatility, as well as product ingredients, influence the purchase 
behaviour of environmentally safe fashion products. $(\mathrm{t}=2.98, \mathrm{p}<.001)$ are having a good significant effect on the purchase behaviour but the appearance which includes attributes like color, brand, and design does not influence the purchase behaviour. By observing this the authors can say that consumer purchase is mainly related to the environment it means which they give importance to the eco-friendly attributes of the product rather than general attributes.

By observing consumer perception towards the activities of the companies (ecofriendly fashion manufacturers), the authors can say that despite buyers' responsibility for the environment, the perceived importance of corporate environmental intervention has no substantial impact on the purchasing behavior of eco-friendly fashion items. It means purchase decisions also depend upon the environmental activities of the company. The more consistency and practicing of marketing strategies related to the environment activities makes a direct or indirect impact on the performance. Which leads to a positive outcome from the consumers.

By observing purchase behaviour of eco-friendly fashion products towards satisfaction $(\mathrm{t}=7.11, \mathrm{p}<.001)$, trust $(\mathrm{t}=4.54, \mathrm{p}<.001)$, and repurchase intention $(\mathrm{t}=$ $6.11, \mathrm{p}<.001)$ having a significant effect. It means the authors can say that consumer's higher purchase of eco-friendly related fashion products leads higher increase in satisfaction, which benefits many companies and help them to produce more products and sell the products. Consumer's trust in the products makes them repurchase the products. This means trust increases then the repurchase intention of the consumer increases. In our study, the authors observed the results in the model the authors can say that the satisfaction impact on the trust $(\mathrm{t}=4.98, \mathrm{p}$ $<.001)$ and satisfaction impact on the repurchase intention $(\mathrm{t}=2.54, \mathrm{p}<.001)$ has a good significant effect which means the higher the consumer satisfaction on the eco-friendly product increases in trust and repurchase intention of the product which also increase the trust in the eco-friendly fashion product manufacturing companies. By observing the trust impact on the repurchase intention $(t=3.06$, $\mathrm{p}<.001)$ the authors can say that Repurchase intention is significantly influenced by trust, which means the higher the trust in the product and the company increases in the repurchase intention of the product. in which there will be also an increase in the recommendation of the product from one customer to other.

\section{Conclusion}

The demand for eco-friendly products increases if there is an increase in the consumer's concern towards the environment. There is high demand for fashion products nowadays. This study is on eco-friendly fashion products which target environmental attitudes of the consumers while purchasing the eco-friendly products and consumers perception towards the eco-friendly attributes or 
characteristics and perceived importance for eco-friendly apparel firms' practices to understand the purchase behaviour of environmentally safe fashion products. Here I have gone with empirical analysis to understand the relationship between them. After doing the empirical study the authors have found the following results, the first thing is attitudes of consumers towards the purchasing behaviour of environmentally safe fashion products the authors understood that purchasing behaviour will be impacted by living needs like household items and concern towards the environmental protection these increases the purchasing behaviour of the eco-friendly products. Here the authors also pointed out that the consumers should be concerned about the environment, and that environmental awareness is critical among consumers. The governments and unions need to increase the environmental policies and regulations to increase the consumer's friendliness towards the environment to increase the purchase of the environmentally safe product. The more concern among the people the more increase in the environmentally safe fashion products purchase.

Second while selecting environmentally safe fashion products consumers prefer the properties like functionality, mark, and packaging of the product rather than design, color, price, and brand of the product. it means consumers show more interest in the eco-friendly attributes of the product rather than general attributes, so fashion industries need to focus more on the eco-friendly fashion products quality. They need to show the information recognizably on the product using mark, label, and packaging. Marketing managers should be aware of these things.

Third, fashion companies need to maintain activities regarding environmental protection in our research it is found that consumers show negative responses towards the activities. It is important for companies to do environmental activities and must improve their activities. Fashion companies need to show social responsibility this may impact their growth directly and indirectly and have a valuable consumer base.

Finally coming to satisfaction, consumers will be more satisfied due to the high purchases of environmentally safe apparel products. If there is high satisfaction among the consumers it will increase the trust among the product and eco-friendly fashion companies, this leads to an increase in the repurchase of the products which will increase product sales. So, fashion companies need to develop trust among the consumers by providing the required information and build their products in terms of good quality which increases their product sales. This will also lead to referring of the product from one consumer to another may to their family, friends, and others.

By this study, the authors may conclude that there is a connection between environmentally safe fashion product attributes and eco-friendly product buying behaviour. It was also discovered that consumer views toward environmental 
protection play a major role in the purchasing of environmentally safe fashion products. Purchase behaviour of environmentally safe fashion goods contributes to satisfaction of the product, trust in the product or the company, and repurchase intention of the product. However, this study is done among few college students it is important to study the model more by changing lifestyles of the consumers and risk of purchasing environmentally safe fashion products...etc. in future research, it is important to explain these terms.

\section{References}

[1] 2012books.lardbucket.org. (2021). Situational Factors That Affect People's Buying Behavior. Retrieved from https://2012books.lardbucket.org/books/marketing-principles-v1.0/s0602-situational-factors-that-affec.html\#: :text=Situational\%20influences\%

[2] Bahadur, B. M., S.. (2019). Green Marketing In India: An Overview. Restaurant Business. doi:http://dx.doi.org/10.26643/rb.v118i8.7503

[3] Beckmann, S. (1993). Everybody seems concerned about the environment: But is this concern reflected in (Danish) consumers' food choice? European Advances in Consumer Research.

[4] Blasi, S. L., Brigato \& Sedita, Silvia Rita. (2019). Eco-friendliness and fashion perceptual attributes of fashion brands: an analysis of consumers' perceptions based on Twitter data mining. Journal of Cleaner Production. doi:http://dx.doi.org/10.1016/j.jclepro.2019.118701

[5] Chan, R. Y. J. P., \& marketing. (2001). Determinants of Chinese consumers' green purchase behavior. 18(4), 389-413.

[6] Cheah, I., Phau, I. J. M. I., \& Planning. (2011). Attitudes towards environmentally friendly products: The influence of ecoliteracy, interpersonal influence and value orientation.

[7] (2013). ETHICAL ASPECTS OF ENVIRONMENTAL MANAGEMENT. Annals of the University of Oradea : Economic Science, 1, 1443-1451.

[8] I., \& Steg, L. J. C. L. (2009). Mean or green: which values can promote stable pro-environmental behavior? , 2(2), 61-66.

[9] Ekinci, G. a. A., Mehmet. (2014). Demographic characteristics of consumer buying behavior effects of environmentally friendly products and an application in Gaziantep.

[10] Huang, H.-C., Lin, T.-H., Lai, M.-C., \& Lin, T.-L. J. I. J. o. H. M. (2014). Environmental consciousness and green customer behavior: An examination of motivation crowding effect. 40, 139-149.

[11] \& Rahman, Z. J. I. S. m. r. (2015). Factors affecting green purchase behaviour and future research directions. 3(1-2), 128-143.

[12] (2015). Importance of Ethical Principles for Eco-friendly Management. ChinaUSA Business Review, 14. doi:10.17265/1537-1514/2015.06.002

[13] Lau, M., \& Cheung, R. (2016). Modelling the Relationship among Green Perceived Value, Green Trust, Satisfaction, and Repurchase Intention of Green Products. Contemporary Management Research, 12.

doi:10.7903/cmr.13842 
[14] M., Sardinha, I. M. D., \& Reijnders, L. J. J. o. c. p. (2012). The effect of corporate social responsibility on consumer satisfaction and perceived value: the case of the automobile industry sector in Portugal. 37, 172-178.

[15] P., Maxwell, J. W. J. R. o. e. e., \& policy. (2008). Corporate social responsibility and the environment: A theoretical perspective. 2(2), 240260.

[16] Majláth, M. (2009). Evaluation of Environmentally Friendly Product Attribute - Results of an Empirical Research. György Kadocsa (ed.),7th International Conference on Management, Enterprise and Benchmarking MEB 2009Proceedings,

[17] Marvi, M. H., Minbashrazgah, M. M., Zarei, A., \& Baghini, G. S. (2020). Knowledge foundation in green purchase behaviour: Multidimensional scaling method. Cogent Business \& Management, 7(1), 1773676. doi:10.1080/23311975.2020.1773676

[18] (2021). 11 Fashion Companies Leading The Way In Sustainability. Retrieved from https://www.forbes.com/sites/blakemorgan/2020/02/24/11fashion-companies-leading-the-way-in-sustainability/?sh=511bc1c16dba

[19] N., Lobo, A., Greenland, S. J. J. o. R., \& Services, C. (2016). Pro-environmental purchase behaviour: The role of consumers' biospheric values. 33, 98-108.

priyanandhini.n, D. m. s. r. (2018). A STUDY ON CONSUMERS LEVEL OF SATISFACTION TOWARDS ECO-FRIENDLY PRODUCTS. - International Journal of Research and Analytical Reviews, 5(4).

[20] Rogers, E. M. (2010). Diffusion of innovations: Simon and Schuster.

Shim, D., Shin, J., \& Kwak, S.-Y. (2018). Modelling the consumer decision-making process to identify key drivers and bottlenecks in the adoption of environmentally friendly products. Business Strategy and the Environment, 27. doi:10.1002/bse.2192

thechicagogreenbox.com. (2020). What is the Importance of Eco-Friendly Products? Retrieved from https://www.thechicagogreenbox.com/themoving-blog/what-is-the-importance-of-eco-friendly-products

[21] Tiwari, S., Tripathi, D. M., Srivastava, U., \& Yadav, P. J. J. o. B. E. (2011). Green marketing-emerging dimensions. 2(1), 18. 